\title{
The Prevalence of Impacted Premolars in the Anatolian Population
}

\section{Anadolu Popülasyonunda Gömülü Premolar Prevalansı}

\section{Seref EZIRGANLI' ${ }^{1}$, Mustafa KIRTAY 3 , Koray OZER², Emin Celalettin UN², Hasan Huseyin KOSGER² Hakki Oguz KAZANCIOGLU1 \\ ${ }^{1}$ Department of Oral and Maxillofacial Surgery, Faculty of Dentistry, Bezmialem Vakif University, Istanbul, Turkey \\ ${ }^{2}$ Department of Oral and Maxillofacial Surgery, Faculty of Dentistry, Cumhuriyet University, Sivas, Turkey \\ ${ }^{3}$ Department of Oral and Maxillofacial Surgery, Faculty of Dentistry, Inonu University, Malatya, Turkey}

\section{ABSTRACT}

Objective: The aim of this study was to determine the prevalence of impacted premolars and the associated pathology of these teeth in the Anatolian population.

Methods: This retrospective cohort study was composed of 10246 panoramic radiographs of patients (6074 females, 4172 males) between 2000 and 2011. We reviewed the panoramic radiographs and clinical data and determined the prevalence of impacted premolars to be associated with sex, age, and number of premolars. We investigated the associated pathology and approach of treatment.

Results: A total of 83 patients ( 43 females, 40 males; mean age $23.42 \pm 11.18$ years, range 12 to 69$)$ had 101 impacted permanent premolars that were either mesioangular $(\mathrm{n}=47,46.54 \%)$, vertical $(n=32,31.68 \% 9)$, distoangular $(n=14,13.86 \%)$, horizontal $(\mathrm{n}=6,5.94 \%)$, and/or buccolingual $(\mathrm{n}=2,1.98 \%)$. Premolar transmigration was absent. Of these premolars, 7 (6.93\%) were associated with cystic lesions. In this study, $61.39 \%$ of impacted premolars were extracted; 39 (38.61\%) were followed up.

Conclusion: The prevalence of impacted premolars in the Anatolian population was determined to be $0.98 \%$. Although premolar impaction is infrequent, early diagnosis is important because most of the cases (93.07\%) are asymptomatic.

Key Words: Impacted premolar, panoramic radiography, prevalence, Anatolian population

\section{ÖZET}

Amaç: Bu çalışmada Anadolu popülasyonunda gömülü premolar prevalansı ve bu dişlerle ilişkili patolojilerin belirlenmesi amaçlanmıştır.

Yöntemler: Bu retrospektif kohort çalışmada 2000 ve 2011 yilları arasındaki 10246 (6074 kadın, 4172 erkek) panaromik radyografi toplanmıştır. Panaromik radyografiler ve klinik bilgiler incelenmiş ve gömülü premolarların sıklığı ile yaş, cinsiyet ve premolar sayısı ilişkisi belirlenmiştir. Patolojiler ve tedavi yaklaşımları incelenmiştir.

Bulgular: Toplam 83 hastada mesioangular $(\mathrm{n}=47, \% 46,54)$, vertical $(\mathrm{n}=32, \% 31,68)$, distoangular $(\mathrm{n}=14, \% 13,86)$, horizontal $(n=6, \% 5,94)$, ve/veya bukkolingual $(n=2, \% 1,98) 101$ gömülü premolar belirlenmişitir. Premolar transmigrasyonu izlenmiştir. Bu premolarların $7(\% 6,93)$ ' si kistik lezyonlarla ilişkilidir. Bu çalışmada, gömülü premolarların \%61,39 çekilmiş, 39 (\%38,61)'u takibe alınmıştır.

Sonuç: Anadolu populasyonunda gömülü premolar prevalansı $\% 0,98$ dir. Premolar gömülüğü çok sık gözükmese de, çoğu vaka asemptomatik olduğu için erken tanı önemlidir.

Anahtar Sözcükler: Gömülü premolar, panoramik röntgen, prevalans, Anadolu popülasyonu

\section{Introduction}

Impacted teeth refer to teeth that fail to erupt on time because of mechanical obstructions (1). The main etiological factors for premolar impaction appear to include arch length deficiency, lack of space, ectopic position of tooth germ, obstacles to eruption such as an ankylosed primary molar, and the presence of supernumerary teeth or odontomas. Some systemic and genetic factors involved include cleidocranial dysplasia, osteopetrosis, Down's syndrome, hypothyroidism, and hypopituitarism (2-4). 
Impacted teeth are important in dentistry (5). Their clinical diagnoses are straight forward, involving a clinical inspection that discloses the absence of the tooth in its normal position combined with radiographic assessment showing the unerupted position of the tooth. Radiographic assessment of impacted teeth is important in the preparation for surgical or orthodontic treatment (6).

Mandibular third molars are the teeth that are most often impacted, followed by maxillary canines, central incisors, and mandibular second premolars (7). These impacted teeth can cause problems in clinical dentistry (8). Although they are mostly asymptomatic, they are sometimes discovered when a patient presents with pericoronitis or pathologies such as a cystic lesion in an adjacent tooth. Thus, the discovery of an impaction usually occurs during a routine visit, and this leads to a late diagnosis (8-10). There are insufficient studies about impacted premolar prevalence in the literature. Therefore, in this retrospective study, we aimed to investigate the prevalence of impacted premolars and the associated pathology of these teeth in the Anatolian population.

\section{Methods}

We retrospectively screened 10246 panoramic radiographs and clinical data of patients (6074 females, 4172 males) from various regions of Anatolia in our clinic between January 2000 and November 2011. Ethical permission was obtained from the ethics committee of Bezmialem Vakif University (no: 2012; 21/26). Panoramic radiographs were reviewed by four oral and maxillofacial surgeons using standard light boxes. Data were collected on the number and localization of impacted premolars of both upper and lower jaws. Moreover, patients' gender and age and also treatment methods were noted.

The percentage and number of impacted premolars according to localization and gender was recorded. Impacted premolars

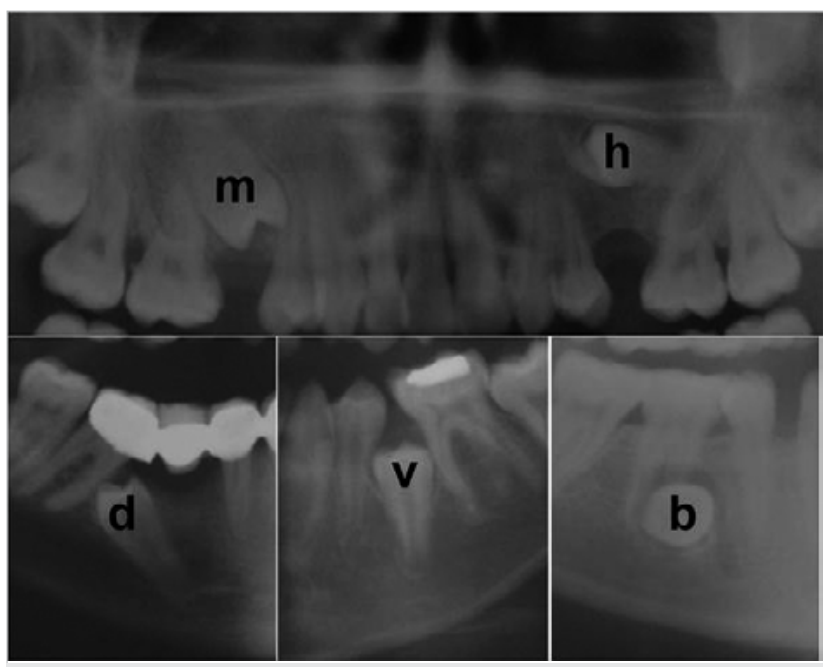

Figure 1. The angulations of impaction classified (m: mesioangular; h: horizontal; d: distoangular; v: vertical; b: bucco-lingual) were recorded based on Winter's classification systems. The angulations of impaction were measured using the Quek et al. (10) method to classify as mesioangular, vertical, distoangular, horizontal and bucco-lingual (Figure 1). The percentage and number of impacted premolars according to tooth angulations were determined. The impaction degree of the impacted premolar was determined as mild, moderate and severe, as defined by Brearley and McKibben (11). The percentage and number of impacted premolars according to impaction degree were recorded. Finally, the pathologies or symptoms associated with impacted premolars and the approach to treatment were examined.

\section{Statistical analysis}

Data were collected and analyzed using NCSS (Number Cruncher Statistical System) 2007\&PASS 2008 Statistical Software (Utah, USA). Descriptive statistics, frequencies, means, medians, standard deviations (SD), and explorative

Table 1. The prevalence of the impacted premolars in 10246 patients

\section{Number Percentage}

(\%)

\begin{tabular}{l|c|l|} 
UPPER JAW & 30 & 0.29 \\
First premolar & 4 & 0.04 \\
Second premolar & 26 & 0.25 \\
LOWER JAW & 71 & 0.69 \\
First premolar & 7 & 0.07 \\
Second premolar & 64 & 0.62 \\
Total & 101 & 0.98
\end{tabular}

Table 2. The number of impacted premolars according to gender

\begin{tabular}{|l|c|c|c|c|c|c|}
\hline & $\begin{array}{c}\text { Number } \\
\text { of patient }\end{array}$ & $\begin{array}{c}\text { Number } \\
\text { of teeth }\end{array}$ & $\begin{array}{c}\text { Lower } \\
\text { jaw }\end{array}$ & $\begin{array}{c}\text { Upper Right } \\
\text { jaw }\end{array}$ & Left \\
\hline Female & 43 & 52 & 40 & 12 & 23 & 29 \\
\hline Male & 40 & 49 & 31 & 18 & 23 & 26 \\
\hline Total & 83 & 101 & 71 & 30 & 46 & 55 \\
\hline
\end{tabular}

Table 3. The 101 impacted premolars according to tooth angulations

\begin{tabular}{|lcc|}
\hline & Number & $\begin{array}{c}\text { Percentage } \\
\text { (\%) }\end{array}$ \\
\hline Mesioangular & 47 & 46.54 \\
Vertical & 32 & 31.68 \\
Distoangular & 14 & 13.86 \\
Horizontal & 6 & 5.94 \\
Bucco-lingual & 2 & 1.98 \\
Total & 101 & 100 \\
\hline
\end{tabular}


data analysis were employed. The Chi-square test was used for comparison of qualitative data. Statistical significance was set at $\mathrm{p}<0.05$.

\section{Results}

The prevalence of the impacted premolars in the $10246 \mathrm{pa}-$ tients was $0.98 \%$ (lower jaw: $0.69 \%$, upper jaw: $0.29 \%$ ) as shown in Table 1 . There was no statistically significant difference between the first and second premolars in terms of the number in the upper and lower jaw $(\mathrm{p}=0.728)$. A total of 83 patients ( 43 females, 40 males; mean age $23.42 \pm 11.18$ years, range 12 to 69 ) had impacted first and second premolars. Table 2 shows the number of impacted premolars according to sex. The number of impacted premolars was the same on the right and left sides of the jaws; however, more than twice as many were found in the lower jaws than in upper jaws. There was no statistically significant difference between the lower and upper jaws, and between the right and left side in terms of sex. The impacted premolars were in a single jaw in 68 patients and in both jaws in 5 patients. The number of impacted premolars was found to be similar in both sexes. In this study, the 101 impacted premolars were either mesioangular $(n=47,46.54 \%)$, vertical $(\mathrm{n}=32,31.68 \%)$, distoangular $(\mathrm{n}=14,13.86 \%)$, horizontal $(n=6,5.94 \%)$, or buccolingual $(n=2,1.98 \%)$ (Table 3). Their impaction degree was considered mild in $12(11.88 \%)$ cases, moderate in 51 (50.5) cases and severe in 38 (37.62\%) cases (Table 4). The pathologies associated with impacted premolars are presented in Table 5 and the approaches to treatments are presented in Table 6. In total, $93.07 \%$ of the impacted premolars were asymptomatic. Cystic lesions were recorded in 7 (6.93\%) of impacted premolars and $62(61.39 \%)$ impacted premolars were extracted.

\section{Discussion}

Impacted teeth are teeth with a delayed eruption time or those that are not expected to erupt completely, according to clinical and radiographic findings (12-15). The impaction of permanent teeth is a relatively common occurrence and can involve any tooth in the dental arch, which presents a clinical problem for orthodontists and oral surgeons. The cause, frequency, complications, and surgical operation of impacted teeth are always interesting subjects for study and research (14).

Various studies associated with the prevalence of tooth impaction have been reported. For example, Hou et al. (14) found $6.15 \%$ in 8912 patients, Saglam and Tuzum (16) found $11 \%$ in 1000 patients, and Ahlqwist and Gröndahl (17) found 8\% in 1418 female patients. The prevalence of impacted premolars has been reported to be $0.5 \%$, with a range of $0.1 \%$ to $0.3 \%$ for maxillary premolars and $0.2 \%$ to $0.3 \%$ for mandibular premolars $(18,19)$. Saglam and Tuzum (16) reported that the prevalence of impaction was $2.67 \%$ for maxillary premolars and $0.76 \%$ for mandibular premolars (16). However, this cannot give us exact information about the prevalence authors carried out their study on a very limited number of patients (1000 patients) and in only a single region. By contrast, we carried out our study on a very large patient population (10246 patients). Although we also carried out our study in a single region, this region was representative of the general Anatolian population. In this study, the prevalence of impacted premolars was $0.29 \%$ for maxillary premolars and $0.69 \%$ for mandibular premolars. Impaction was the most frequent in mandibular second premolars $(0.62 \%)$ followed by maxillary second premolars $(0.25 \%)$, mandibular first premolars $(0.07 \%)$, and maxillary first premolars $(0.04 \%)$. Saglam and Tuzum (16) recorded the prevalence of impacted premolars as $1.52 \%$ in females and $1.91 \%$ in males. In our study, we recorded this prevalence as $0.50 \%$ in females and $0.48 \%$ in males. However, the previous researchers did not find impacted mandibular premolars in males, whereas we recorded the prevalence as $0.30 \%$.

Tooth impaction may be vertical, mesioangular, distoangular, horizontal, buccolingual, and even inverted (14, 20, 21). Hou et al. (14) studied the prevalence of impacted permanent teeth except for third molars in a Chinese population and found that vertical impaction occurred the most often (49.09\%) followed by mesioangular (26.46\%), horizontal $(8.58 \%)$, distoangular $(6.20 \%)$, buccolingual $(5.11 \%)$, and inverted $(4.56 \%)$ impaction. In their study of impacted first

\begin{tabular}{|c|c|c|}
\hline Impaction degree & Number & $\begin{array}{c}\text { Percentage } \\
\text { (\%) }\end{array}$ \\
\hline Mild & 12 & 11.88 \\
\hline Moderate & 51 & 50.50 \\
\hline Severe & 38 & 37.62 \\
\hline Total & 101 & 100 \\
\hline
\end{tabular}

Table 5. The pathologies associated with impacted premolars

\section{Number Percentage}

(\%)

\begin{tabular}{l|c|c|}
$\begin{array}{l}\text { The presence of } \\
\text { cystic lesion }\end{array}$ & 7 & 6.93 \\
\hline $\begin{array}{l}\text { Asymptomatic } \\
\text { Total }\end{array}$ & 94 & 93.07 \\
& 101 & 100
\end{tabular}

Table 6. Treatment approach

\begin{tabular}{|l|c|c|}
\hline & Number & $\begin{array}{c}\text { Percentage } \\
\text { (\%) }\end{array}$ \\
\hline Extraction & 62 & 61.39 \\
\hline Follow-up & 39 & 38.61 \\
\hline Total & 101 & 100 \\
\hline
\end{tabular}


and second molars in a Turkish population, Bereket et al. (9) also recorded that vertical impaction occurred the most often $(62.5 \%)$, followed by horizontal $(8.5 \%)$, mesioangular (19\%), distoangular (6\%), and buccolingual (3.5\%) impaction. From our results, we recorded the impacted premolars were the most often mesioangular $(46.54 \%)$ followed by vertical $(31.68 \%)$, distoangular (13.86\%), horizontal (5.94\%), and buccolingual $(1.98 \%)$ positions. Premolar inversion is very rare; few cases have been reported in the literature, and the majority of cases are limited to radiographic findings (20). In the present study, we did not record transmigrated premolars or inverted impaction of premolars.

Tooth impaction may be the result of caries, pulp disease, periapical and periodontal disease, root resorption of the adjacent tooth, and even oral and maxillofacial tumors. Diagnosis and treatment may be very troublesome for dentists. Also, its management is important aesthetically and functionally to the patient. Thus, the early identification of tooth impaction is of critical interest to researchers (14). However, this study showed that most (93.07\%) of the impacted premolars were asymptomatic. Thus, we consider that, although premolar impaction is infrequent, early diagnosis is important. In addition, unerupted and impacted premolars can be a problem for orthodontists and oral surgeons, and the approach to managing these teeth are still an area of controversy $(8,22)$. Orthodontic treatment options should be considered (23). Various surgical approaches and orthodontic techniques have been suggested to expose the tooth and move it into the arch (22). Halazonetis (23) was able to apply orthodontic treatment to a patient with a horizontally impacted maxillary premolar. Yawaka et al. (24) successfully applied orthodontic treatment to a patient with both impacted mandibular premolars, one of them associated with a cystic lesion. In addition, Yahara et al. (25) showed that 15 of $21(71.4 \%)$ mandibular premolars associated with dentigerous cyst erupted; half of them erupted within 3 months, and all 15 erupted completely within 10 months after marsupialization without orthodontic traction. Treatment options for these teeth included observation, intervention, relocation, and extraction. On occasion, some interaction may occur among these treatment options. Observation involves no treatment other than monitoring the patient clinically and radiographically (19). Assessment of all the clinical and radiographic findings is fundamental when deciding upon a suitable treatment plan (8). In this study, we recorded cystic lesions in 7 (6.93\%) impacted premolars, and $61.30 \%$ of the impacted premolars were extracted. Only one case required orthodontic treatment.

\section{Conclusion}

The prevalence of impacted premolars in the Anatolian population was determined to be $0.98 \%$. Although premolar impaction is infrequent, early diagnosis is important because most cases are asymptomatic.
Conflict of Interest: No conflict of interest was declared by the authors.

Financial Disclosure: The authors declared that this study has received no financial support.

Peer-review: Externally peer-reviewed.

Ethics Committee Approval: Ethics committee approval was received for this study from the ethics committee of Bezmialem Vakif University (2012-21/26).

Informed Consent: Written informed consent was not obtained due to the retrospective nature of the study.

Author Contributions: Concept - Ş.E.; Design - Ş.E.; Supervision M.K.; Funding - K.Ö.; Materials - E.C.Ü.; Data Collection and/or Processing - M.K., Ş.E.; Analysis and/or Interpretation - H.H.K.; Literature Review - H.H.K.; Writing - Ş.E.; Critical Review - H.O.K.

Çıkar Çatışması: Yazarlar çıkar çatışması bildirmemişlerdir.

Finansal Destek: Yazarlar bu çalışma için finansal destek almadıklarını beyan etmişlerdir.

Hakem değerlendirmesi: Dı̧̧ bağımsız.

Etik Komite Onayı: Bu çalışma için etik komite onayı Bezmialem Vakif Üniversitesi Etik Komitesinden’ den alınmıştır (2012-21/26).

Hasta Onamı: Çalışmanın retrospektif tasarımından dolayı hasta onamı alınmamıştır.

Yazar Katkıları: Fikir - Ş.E.; Tasarım - Ş.E.; Denetleme - M.K.; Kaynaklar - K.Ö.; Malzemeler - E.C.Ü.; Veri toplanması ve/veya işlemesi - M.K., Ş.E.; Analiz ve/veya yorum - H.H.K.; Literatür taraması - H.H.K.; Yazıyı yazan - Ş.E.; Eleştirel İnceleme - H.O.K.

\section{References}

1. Ozan F, Kara I, Ay S. Impacted mandibular permanent incisors associated with a supernumerary tooth: a case report. Eur J Dent 2009; 3: 324-8.

2. Collett AR. Conservative management of lower second premolar impaction. Aust Dent J 2000; 45: 279-81. [CrossRef]

3. Hicks MJ, Greer RO Jr, Flaitz CM. Delayed eruption of maxillary permanent first and second molars due to an ectopically positioned maxillary third molar. Pediatr Dent 1985; 7: 53-6.

4. Mariano RC, Mariano Lde C, de Melo WM. Deep impacted mandibular second molar: a case report. Quintessence Int 2006; 37: 773-6.

5. Joshi MR. Transmigrant mandibular canines: a record of 28 cases and a retrospective review of the literature. Angle Orthod 2001; 71: 12-22.

6. Zeitler DL. Management of impacted teeth other than third molars. In: Miloro M, editor. Peterson's principles of oral and maxillofacial surgery. London: BC Decker Inc; 2004.p.131-7.

7. Tarazona B, Paredes V, Llamas JM, Cibrian R, Gandía JL. Influence of first and second premolar extraction or non-extraction treatments on mandibular third molar angulation and position. A comparative study. Med Oral Patol Oral Cir Bucal 2010; 15: 760-766. [CrossRef]

8. Murray P, Brown NL. The conservative approach to managing unerupted lower premolars-two case reports. Int J Paediatr Dent 2003; 13: 198-203. [CrossRef]

9. Bereket C, Çakir-Özkan N, Şener I, Kara I, Aktan AM, Arici N. Retrospective analysis of impacted first and second permanent molars in the Turkish population: A multicenter study. Med Oral Patol Oral Cir Bucal 2011; 16: 874-878. [CrossRef] 
10. Quek SL, Tay CK, Tay KH, Toh SL, Lim KC. Pattern of third molar impaction in a Singapore Chinese population: a retrospective radiographic survey. Int J Oral Maxillofac Surg 2003; 32: 548-52. [CrossRef]

11. Brearley LJ, McKibben DH Jr. Ankylosis of primary molar teeth. I. Prevalence and characteristics. ASDC J Dent Child 1973; 40: 5463.

12. Kemp WB. Impaction of a mandibular first permanent molar. Oral Surg Oral Med Oral Pathol 1980; 49: 95. [CrossRef]

13. Burch J, Ngan P, Hackman A. Diagnosis and treatment planning for unerupted premolars. Pediatr Dent 1994; 16: 89-95.

14. Hou R, Kong L, Ao J, Liu G, Zhou H, Qin R, et al. Investigation of impacted permanent teeth except the third molar in Chinese patients through an X-ray study. J Oral Maxillofac Surg 2010; 68: 762-7. [CrossRef]

15. Thilander B, Jakobsson SO. Local factors in impaction of maxillary canines. Acta Odontol Scand 1968; 26: 45-68. [CrossRef]

16. Sağlam AA, Tüzüm MS. Clinical and radiologic investigation of the incidence, complications, and suitable removal times for fully impacted teeth in the Turkish population. Quintessence Int 2003; 34: 53-9.

17. Ahlqwist M, Gröndahl HG. Prevalence of impacted teeth and associated pathology in middle-aged and older Swedish women. Community Dent Oral Epidemiol 1991; 19: 116-9. [CrossRef]
18. Oikarinen VJ, Julku M. Impacted premolars. An analysis of 10000 orthopantomograms. Proc Finn Dent Soc 1974; 70: 95-8.

19. McNamara C, McNamara TG. Mandibular premolar impaction: 2 case reports. J Can Dent Assoc 2005; 71: 859-63.

20. Shashikiran ND, Kumar NC, Reddy VV. Unusual presentation of inverted impacted premolars as a result of dentigerous cyst: a case report. J Indian Soc Pedod Prev Dent 2006; 24: 97-9. [CrossRef]

21. Shapira Y, Kuftinec MM. Early diagnosis and interception of potential maxillary canine impaction. J Am Dent Assoc 1998; 129: 1450-4. [CrossRef]

22. Shapira Y, Borell G, Kuftinec MM, Stom D, Nahlieli O. Bringing impacted mandibular second premolars into occlusion. J Am Dent Assoc 1996; 127: 1075-8. [CrossRef]

23. Halazonetis DJ. Horizontally impacted maxillary premolar and bilateral canine transposition. Am J Orthod Dentofacial Orthop 2009; 135: 380-9. [CrossRef]

24. Yawaka Y, Kaga M, Osanai M, Fukui A, Oguchi H. Delayed eruption of premolars with periodontitis of primary predecessors and a cystic lesion: a case report. Int J Paediatr Dent 2002; 12: 53-60. [CrossRef]

25. Yahara Y, Kubota Y, Yamashiro T, Shirasuna K. Eruption prediction of mandibular premolars associated with dentigerous cysts. Oral Surg Oral Med Oral Pathol Oral Radiol Endod 2009; 108: 28-31. [CrossRef] 